\title{
Let's Not Retreat in the Fight Against Inflation
}

\author{
A speech by DARRYL R. FRANCIS, President, Federal Reserve Bank \\ of St. Louis, before the Mississippi Bankers Association Convention, \\ Buena Vista Hotel, Biloxi, Mississippi, May 19, 1970
}

\begin{abstract}
HIS IS A WELCOME OPPORTUNITY to discuss my view of the state of our economy with friends of long standing, the bankers of Mississippi. As business leaders in Mississippi and in your local communities, it is, of course, always important that you keep in touch with economic stabilization efforts to promote a high level of employment and relatively stable prices. At this particular time, I want also to diseuss with you some pitfalls which could threaten the success of those efforts and defeat their objectives.
\end{abstract}

By way of background, I will examine two topics, tracing first the development of our inflation since 1965, and next, some reasons for the extremely slow response of inflation to monetary and fiscal restraint of the past two years. This background is essential to my principal point which is this - a possible threat to the success of current stabilization actions. This threat comes from some frequently expressed desires to achieve several good but incompatible objectives by year's end - namely, a markedly lower rate of inflation, little further rise in unemployment, and a sharp reduction in market interest rates. I say actions to accomplish these short-run objectives constitute a threat because attaining any one of them would require extreme monetary actions, leading to later conditions quite contrary to desired policy objectives. Moreover, these near-term objectives cannot be achieved simultaneously.

In developing the background topics and outlining the possible impediments to achieving current policy objectives, my remarks will draw heavily on recent research at the Federal Reserve Bank of St. Louis. For the past two years our economists have been attempting to quantify the response of total spending, real output, the price level, the unemployment rate, and market interest rates to monetary and fiscal actions. Monetary actions in this research are measured by changes in the nation's money stock - that is, demand deposits and currency held by the nonbank public. Fiscal actions refer to changes in spending and taxing provisions of the Federal Government budget.

One important conclusion suggested by these studies is that actions of the Federal Reserve which change the rate of monetary expansion exert a relatively quick and pervasive influence on total spending, and changes in Federal Government expenditures relatively less, unless accompanied by accommodating changes in the money stock. Changes in Federal taxing provisions are found to have an insignificant influence on total spending.

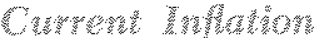

I turn now to my first background topic - an examination of our inflation since 1965. After six years of relative price stability from 1958 to 1964 , we have since experienced accelerating inflation. The general price level rose at a three per cent annual rate from late 1965 to mid-1967, then at a four per cent rate to the end of 1968, and finally, during the past five quarters, at a five per cent rate. The inflation rate shows few signs of abating up to now.

This five-year record of accelerating inflation resulted from the pressure of total spending on the ability of our economy to produce goods and services, particularly since early 1966. From the first quarter of 1966 to mid-1968, total spending rose at a 7.5 per cent annual rate, while output of goods and services grew at about a four per cent rate, or approximately the rate of growth of the economy's productive potential. At full employment of our resources, expansion of real output depends on growth in the labor force, capital plant, and technology. In recent years these factors have fostered growth of production potential at about a four per cent annual rate.

By 1968 and 1969, inflation had developed a very strong momentum which has complicated greatly the problem of reducing the rate of increase of prices. 
This momentum is the result of households, businesses, and labor unions attempting to protect their economic positions by building anticipated price in creases into contracts for goods, services, and loans. In this manner, the "demand pull" inflation of 1965 to 1968 was subsequently changed into "cost push" inflation. I want to point out, however, that excessive total spending was the basic catuse of our present inflation problem, and that the so-called cost push inflation is also at result of earlier excessive totat demand.

Where did the excessive increase in total spending come from? Mainly it was a result of overly expansive monetary actions. The money stock increased from April 1965 to April 1966 at a six per cent annual rate, at that time the fastest rate since the inflationary period of the Korean War. Following 1966 when the money stock remained unchanged for eight months, money grew at a seven per cent rate during 1967 and 1968, the most rapid rate since World War II.

That period when the money stock remained unchanged during the last eight months of 1966 set the stage for curbing inllation. This could have led to a balanced rate of spending if it had not been followed by resumption of expansion in money at a very rapid rate in 1967 and 1968. Out studies indicate that if expansion in money had been maintained at a moderate four per cent rate instead of the seven per cent rate actually recorded in 1967 and 1968 , the rate of inflation since late 1966 most likely would not have surpassed 3.5 per cent, instead of reaching five per cent as it did last year. Moreover, if the four per cent growth in money had been maintained up to the present, the rate of inflation would be receding, and if that moderate rate of monetary expansion were to be continued through 1972, price increases would be down to about a 1.5 per cent rate by the end of that year.

Excessive total spending has not only been the cause of price inflation but also of the great increase of market interest rates during the past four years. Our research indicates that market interest rates are highly responsive to anticipated price changes. Past increases in the price level, such as those during the last five years, cause participants in the money and capital markets to expect a continued high rate of inflation. An inflationary premium is thus built into market interest rates. We attribute almost all of the sharp rise in market interest rates since 1966 to an accelerating inflation fostered by excessive monetary expansion.

As was the case with the general price level, the monetary restraint of 1966 set the stage for lower interest rates. Our studies indicate that a moderate four per cent growth in money from the end of 1966 to the end of 1969 would have produced a peak in short-term interest rates, as measured by the rate on four- to six-month commercial paper, of around 5.5 per cent, and these interest rates would have been about 4.5 per cent this spring, instead of the present eight per cent or more. Further continuation of this moderate growth in money would have produced shorttem interest rates heading to below four per cent by late 1972 . Long-term interest rates would have moved in a similar manner. With a four per cent growth in money, seasoned corporate Aad bond rates would have probably peaked at about 6.25 per cent, would likely have been about 6 per cent this spring compared with the actual level of almost 8 per cent, and would be moving to about 5 per cent in late 1972.

It must be evident to everyone that our failure to take advantage, during 1967-1968, of the eight months of restraint in 1966 was a golden opportunity lost. Had the period of restraint been followed by a moderate, instead of rapid monetary expansion, the many conomic dislocations caused by the continuation of high and accelerating rates of inflation after 1966 could have been prevented. Commercial banks and savings institutions could have done very well with short-term market interest rates not in excess of 5.5 per cent, as these institutions would not have undergone the problems caused by the disintermediation of the last three years.

Furthemore, the housing industry would have been in much better condition throughout this period. Labor contract negotiations today would have been less acrimonious and disruptive. And, of course, the whole of society would have benefited by a lesser rate of inflation.

A logical question to be asked is, "Why was this opportunity to control inflation lost?" The published record and statements of prominent economists indicate several reasons. First, there was the mistaken belief at the time that easing actions of monetary authorities could prevent increases in market interest rates in the short run or, as some argued, actually lower them permanently. Such actions were deemed desirable in order to shelter savings institutions and the housing industry from market forees set in motion by the excessive total spending. Second, many argued that monetary actions, as indicated by changes in the money stock, have little influence on total spending. As a consequence, those holding this view were little disturbed by the exceedingly rapid growth in the money stock. Third, in contrast with the previous 
view, many believed that rapid growth in money was desirable in early 1967 to avoid an anticipated recession. Finally, the national debt was increasing, and it was thought desirable by many that the Federal Reserve "even keel" the money markets at times of Treasury financings.

All of these reasons have proven to have been spurious. The resumption of rapid monetary growth in 1967 and 1968 gave us higher interest rates, not lower; less funds for housing, not more; greater strains in the financial markets, not less; and more difficulty with managing the Federal debt, not less.

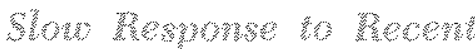

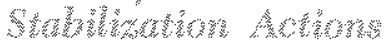

With inflation mounting, restraining actions have been adopted since mid-1968, but the response of inflation has been agonizingly slow. People naturally ask why. The answer is fairly simple - as a result of avoiding monetary actions to curb inflation until 1969 , an inflationary momentum was allowed to develop. As a result, the general price level has continued to rise rapidly up to the present time, and market interest rates remain near their extremely high levels of late 1969. This is the legacy of the excessive total spending from 1965 to 1968 , which requires more restraint and patience to overcome now that inflation is moving under its own momentum.

As a step toward restraint, monetary expansion was reduced to a four per cent rate during the first half of 1969. Further restraint was applied in the second half of 1969 when there was no growth in money. The impact of such monetary actions has fallen primarily on total spending and real output of goods and services and not, as yet, to any appreciable extent, on the price level.

Some have begun to question whether monetary restraint will result in slower growth in the price level in a reasonable period of time. But our research indicates that a marked move to monetary restraint, such as we had in 1969, generally slows total spending with only a two- to three-quarter lag, and this was the case in 1969. Such a change in the rate of growth of total spending is accompanied by a simultaneous decrease in the rate of growth of output. And so it was in the last year. It is not until a further two or three quarters that prices respond appreciably to the slower growth in spending. So we should not have expected price restraint in 1969. The course of the price level depends not only on total spending but also on anticipated price movements. The greater the anticipated rise in prices, the longer delayed is the response of the price level to monetary restraint. This is what we mean by the problem of inflationary momentum.

So here we are again in 1970 , with the stage set for reducing the rate of price increase, just as was the situation at the beginning of 1967. But 1970 is not exactly like 1966: inflation has built up a longer and stronger momentum since then. Consequently, it is more difficult to curb inflation this time; and the public, as well as economic policy makers, must be patient in waiting for the results of monetary restraint to appear.

Many have become concerned that the extreme monetary restraint of 1969 may result in excessive retardation of economic growth and have recommended a resumption of monetary expansion. $I_{2}$ too, share these concerns, and I favor a moderate rise in the money stock. We should avoid, however, a repeat of the 1967-1968 experience when concern over a possible recession was one of the major bases for excessively stimulative monetary actions. This effort will take time-longer than it would have taken if pursued to completion following 1966. Now, as many as three more years will probably be required for the rate of price advance to fall below two per cent, assuming a moderate rate of growth in the money stock.

While moderate growth in money will reduce price increases to a tolerable rate by late 1972 , this achievement will not be without some transitional costs. During the next three years, growth of real output would remain below the economy's productive potential, and, as a result, the unemployment rate would continue to increase. If our measurements of the response of prices and unemployment to stabilization actions are reasonably correct, and I believe they are, the excesses of 1965 to 1968 cannot be corrected without temporary costs in terms of lost output and employment opportunities.

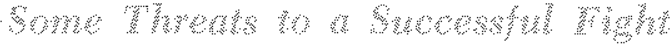

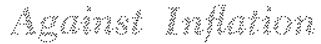

I turn now to my final subject - some possible threats to a successful fight against inflation. Many may not be satisfied with the price level, output, unemployment, and interest rate movements between now and late 1972 that I have just indicated are likely to follow from a moderate rate of monetary expansion. Many recommend that present stabilization actions be altered so that in 1970 the rate of inflation be reduced to below four per cent. Others argue that the unemployment rate should not be al- 
lowed to reach five per cent this year. Some propose that market interest rates be reduced markedly in the near term. It is argued that once these immediate objectives have been achieved, moderate monetary growth can safely be resumed in 1971 and 1972.

But these desired accomplishments are not mutually compatible. To achieve any one of them this year, we are probably not willing to consciously pay the costs in terms of the other two. In addition, achieving any one of these short-run objectives may set in motion forces which would lead to unacceptable con sequences at the end of two or three years.

I have already indicated that a policy of moderate four per cent rate of monetary expansion during the next three years will most likely produce reasonably stable prices by late 1972 , along with lower interest rates. Let us now examine the implications for late 1972 of alternative monetary policies over the balance of this year which would be designed to achieve the three short-run objectives I have just outlined. In each case, I will assume, after 1970 , a four per cent rate of growth in money. Given the existing inflationary momentum, extreme monetary actions in terms of growth in money would be required to achieve any one of the three objectives by the end of this year.

Let us first examine the proposal that the rate of inflation be reduced below four per cent by the end of this year. Many have actually forecast a rate of price increase in the 3.5 to 4 per cent range. In order to accomplish this objective - a rate of inflation below four per cent - the money stock would have to be decreased at about a four per cent rate from the first to the fourth quarter. The price situation would be very good in 1972, when the price level would be rising very slowly. Such an action would result now, however, in an extremely severe recession. Output would probably decrease sharply during the next five quarters, and the unemployment rate would be markedly higher in 1972 than now. In my opinion, the employment and output costs of attaining rapid price level restraint in 1970 would be far too high for it to be given serious consideration.

The next shorturun proposal to be examined is the one calling for actions to avoid further recession and to hold the unemployment rate below five per cent during the remainder of this year. This proposal is based on the same kinds of fears of a recession as, in early 1967 , led to a high rate of growth in the money stock. Accomplishment of this objective, according to our studies, would require a ten per cent rate of monetary expansion during the last three quarters of this year.
Such a course of monetary action would provide little reduction in the rate of price advance this year and a rate of inflation still in excess of three per cent in late 1972. It could be said that this would be very slow progress in curbing inflation, and I would agree. This course of monetary expansion would result in only a temporary spurt of growth in real output. By 1972, as a result of the shift back to a moderate rate of monetary expansion, real output would be growing at about half the increase in full employment potential. Consequently, the unemployment rate would most likely increase to above 5 per cent by late 1972 .

Finally, I would like to consider the possibility of achieving a sharp and immediate reduction in market interest rates. Such an objective has been suggested, just as in 1967 and 1968, in order to help savings institutions and the housing industry. With respect to long-term interest rates, because the inflation premium incorporated in them is so great, the rates could be affected only slightly by year's end even with extremely rapid monetary expansion. Furthermore, if rapid monetary expansion were used to reduce longterm rates this year, these rates would remain at relatively high levels through 1971 and into 1972. With respect to short-term rates, we may expect some declines this year if money supply increases only moderately. More rapid monetary expansion could bring slightly greater declines, but at the expense of higher rates in 1971 and 1972 .

Pursuit of such an interest rate policy would result in no headway in controlling inflation this year and only slight improvement by 1972 . As a result of the continuing high rate of inflation, short-term interest rates would soon return to their present levels, or higher, and long-term rates would rise further from their present levels. The year 1972 would still be one of high interest rates. But that is not the whole picture; the shift back to a moderate rate of money growth after this year would result in very slow in creases in output in 1972 accompanied by a rising unemployment rate.

The preceding analysis suggests several implications. First, given the existing momentum of inflation, relatively stable prices cannot be achieved in a short period of time, unless we are prepared to accept very high costs in terms of reduced output and employment. Second, monetary actions in 1970 to achieve the short-run employment and interest rate objectives mentioned are self-defeating over the longer run. Third, delaying moderate monetary expansion until after the end of this year, in order to achieve these unemployment and interest rate objectives, would 
seriously impede efforts to curb inflation within the next three years. Finally, if we are to contain inflation, there will be accompanying output and employment costs. Such costs can be postponed this year by high growth rates in money, but they cannot be avoided if we are ever to achieve relative price stability.

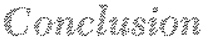

In conclusion, it is my opinion that the current resumption of monetary expansion be kept moderate and maintained for at least the next three years. Such a course, in my view, is optimal - it would produce relative price stability by 1972 without incurring as high a cost in terms of output and employment as would a more restrictive course of action. Although unemployment would rise, this problem in the long run cannot be treated by monetary and fiscal policy and should be treated by other means. For example, better approaches to ameliorate unemployment would be to remove the many impediments to the free functioning of our labor markets, to improve the mobility of our labor force, and to upgrade the skills of the disadvantaged.

As at the beginning of 1967, the stage is now set for achieving relatively stable prices. Let us firmly resolve to seize the opportunity. Let us further resolve that our patience will be equal to the time required. Above all, let us not throw away this opportunity for achieving price stability, as we did a few years ago. If we do, not only will our efforts to date go for nothing, but the battle against inflation will be more difficult and more costly the next time we attempt to make a stand. So this time, let's not retreat in the fight against inflation. 